\title{
DE MÉNONVILLE Siena-Antonia. - An Anthropology of Images in Contemporary Christian Orthodox Ethiopia
}

\section{Reidulf Molvaer}

\section{(2) OpenEdition}

\section{Journals}

\section{Electronic version}

URL: https://journals.openedition.org/etudesafricaines/35977

DOI: 10.4000/etudesafricaines.35977

ISSN: 1777-5353

\section{Publisher}

Éditions de l'EHESS

\section{Printed version}

Date of publication: 29 November 2021

Number of pages: $932-934$

ISBN: 9782713228797

ISSN: 0008-0055

\section{Electronic reference}

Reidulf Molvaer, "DE MÉnonville Siena-Antonia. - An Anthropology of Images in Contemporary Christian Orthodox Ethiopia", Cahiers d'études africaines [Online], 244 | 2021, Online since 29 November 2021, connection on 01 December 2021. URL: http://journals.openedition.org/etudesafricaines/35977 ; DOI: https://doi.org/10.4000/etudesafricaines.35977

This text was automatically generated on 1 December 2021.

(c) Cahiers d'Études africaines 


\title{
DE MÉNONVILLE Siena-Antonia. - An Anthropology of Images in Contemporary Christian Orthodox Ethiopia
}

\author{
Reidulf Molvaer
}

\section{REFERENCES}

DE MÉNONVILLE Siena-Antonia. - An Anthropology of Images in Contemporary Christian Orthodox Ethiopia. Toronto-Paris, L'Harmattan, 2019, 385 p., bibl., gloss., ill.

1 Many scholars have studied Ethiopia, and books that break new ground are most welcome. There are many kinds of books, some full of theory based on scant empirical research (academics in some countries stress this more than others). Some are full of facts combined with only a small degree of insight, somewhat of a journalistic kind. It is refreshing to read a book that combines both: sound theory and solid facts.

2 The book under review is an adapted version of the doctoral dissertation of SienaAntonia de Ménonville. ${ }^{1}$ It shows that she has a firm grasp of anthropological theory, far beyond what most of us can digest. However, what impresses me most is perhaps that she has been able to collect first-hand ethnographic material from practitioners in her research field.

Her primary research focuses on the production, meaning, and impact of images in Ethiopia and then principally icons in the Ethiopian Orthodox Church. There have been studies of paintings in Ethiopia before. In 1964, J. Leroy published La pittura etiopica, ${ }^{2}$ which contains many beautiful pictures and where the author comments individual pictures. In 2008, Tsehai Publishers issued Zerihun Yetmgeta, The Magical Universe of Art. ${ }^{3}$ The art of Afewerk Teklé has also been publicized and commented on by Richard Pankhurst. ${ }^{4}$ It is noteworthy that artists counted primarily as "secular" artists also 
paint for the church. Afework Tekle was asked to paint for churches. Furthermore, in the book about Zerïhun Yetimgéta (in a phonetically correct spelling of his name), one of the contributors, Abebe Zegeya, writes: "Ethiopian Christians are largely unconcerned about religious dogma; they have an abiding belief in traditional prayers, magical practices, spirits, and demons. Zerihun's art is in many respects an art of the people." That is also my impression from conversations with Zerihun and visits to his studio. The blending of the secular and the sacred is far from an uncommon phenomenon for Ethiopian artists.

4 Therefore, it is highly appropriate for Dr de Ménonville to combine in her study images in Christian Orthodox Ethiopia (primarily icons) with magic paintings. Both kinds of images may be executed by the same painter. Therefore, it is a remarkable feat to have been able to meet and interview painters who work in both "fields." Many artists are unwilling to discuss their art in detail, and this is not least the case among painters of an art surrounded by so much secrecy. This is not least the case for painters of magic scrolls. I have also studied such scrolls and commented on them, but I was never able to interview the painters of such scrolls. I find it therefore the more impressive that $\mathrm{Dr}$ de Ménonville has been able to meet and discuss the art of such executioners. They have even been willing to explain their art and function in detail and answer critical questions, something very few have been able to do. This reveals an exceptional talent for sensitive fieldwork, combined with strong analytical capabilities. This is what many of us would have liked to have done and been able to.

5 I tried to be open for and receptive about most things that interested Ethiopians in my insatiable curiosity about a society that enchanted me. I found easy access to sources in connection with the study of history, literature, health (including sex and its healthrelated consequences), child-rearing, family life, and-not least-religion. However, I never got to understand the specific aspects of their art, least of all their religious art (as I also mention in my book Tradition and Change in Ethiopia ${ }^{5}$ ). It is therefore a great feat of Dr de Ménonville to have been able to study the art of Ethiopia with personal appreciation and a strong analytical mind, combined with the understanding of this art by the painters themselves. This is pioneering work of the first order.

6 It is not too difficult to discuss art with modern artists. I did so with a few of them, and they are willing to talk about their art. However, traditional artists who dabble in both the sacred and the profane (which is customarily stigmatized and regarded as sinful) and usually regard the "secrecy" of their art as one of its cherished assets do not easily open up about their trade. It is an art in itself to elicit the "secrets" many such artists associate with their art. Therefore, the author has combined art appreciation with personal approaches (by artists themselves and by "ordinary people"). What does sacred and magic art mean to "the common man and woman," and how is it used? Answers to many such questions we find in this insightful book. There are few books about Ethiopia I have learned so much from as this dissertation. I can only hope that similar studies on related themes may follow it.

7 After an introduction about method, we get to know image producers and their images, both images made for or commissioned by the Church and how believers respond to such images. Neither sacred art nor magic paintings are merely for observation: they are meant to be "effective"-either to shape morals or fulfil the wishes of those who "commission" magic art. The author has wisely used research assistants who represent two different traditions, one an Orthodox Christian and one a Protestant who has been 
converted from an Orthodox background. The fact that the author has spent many years, off and on, in Ethiopia and has learned Amharic, gives depth and credibility to her study. That she has been able to move so dexterously between various theories of art and cultural theories is impressive. I think that she has understood Ethiopian culture better than most of us who have done our best to penetrate this rich and mysterious culture.

8 To add a personal note: few books have made me realize my ignorance about Ethiopia in a vital field more than this dissertation by Dr Siena-Antonia de Ménonville. I look forward to reading more research from her.

\section{NOTES}

1. S.-A. DE MÉNonVILLE, Image in Decency: An Anthropology of Christian Orthodox Image Production in Ethiopia Today, PhD, Paris, Université Sorbonne Paris Cité, 2017. An Italian translation of her book was published in 2020.

2. J. LEROY, La pittura etiopica, Milan, Electa Editrice, 1964; English translation: Ethiopian Painting, London, Merlin Press, London, 1967.

3. A. ZEGEYE, Zerihun Yetmgeta. The Magical Universe of Art, Los Angeles, Tsehai Publishers; Pretoria, Unisa Press ("Zoma Contemporary Art Series"), 2008.

4. R. PANKHURST, The Life and Selected Works of Maitre Artiste Afewerq Tekle, Addis Abeba, n. p., 1987.

5. R. K. Molvaer, Tradition and Change in Ethiopia. Social and Cultural Life as reflected in Amharic Fictional Literature ca. 1930-1974, Los Angeles, Tsehai Publishers, 2008 [1980].

\section{AUTHORS}

\section{REIDULF MOLVAER}

Peace Research Institute, Oslo, Norway 